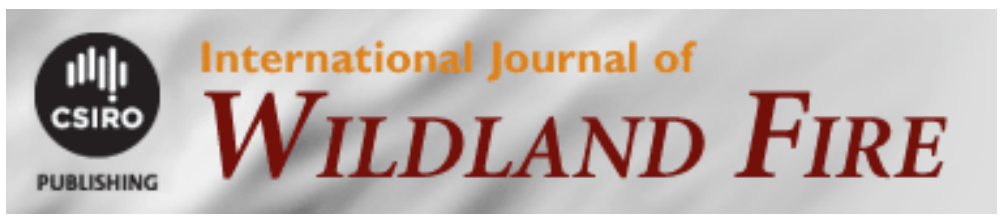

\title{
Assessment of the influence of biophysical properties related to fuel conditions on fire severity using remote sensing techniques: a case study on a large fire in NW Spain
}

\begin{tabular}{|r|l|}
\hline Journal: & International Journal of Wildland Fire \\
\hline Manuscript ID & WF18156.R2 \\
\hline Manuscript Type: & Research Note \\
\hline Author: & n/a \\
\hline Complete List of Authors: & $\begin{array}{l}\text { García-Llamas, paula; Universidad de Leon, Biodiversity and } \\
\text { Environmental Management } \\
\text { Suarez-Seoane, Susana; University of Leon, Area de Ecologia. Dpto. } \\
\text { Biodiversidad y Gestion Ambiental } \\
\text { Taboada, Angela; Universidad de Leon, Biodiversity and Environmental } \\
\text { Management } \\
\text { Fernández-García, Víctor; Universidad de Leon, Biodiversity and } \\
\text { Environmental Management } \\
\text { Fernández-Guisuraga, José Manuel; Universidad de Leon, Biodiversity } \\
\text { and Environmental Management } \\
\text { Fernández-Manso, Alfonso } \\
\text { Quintano, Carmen } \\
\text { Marcos, Elena; Universidad de Leon, Biodiversity and Environmental } \\
\text { Management } \\
\text { Calvo, Leonor; Univ de Leon, Fac de Ciencias Biologicas y Ambientales }\end{array}$ \\
\hline Keyword: & Fire severity, Fuel, Ecosystems: temperate, Fire management \\
\hline
\end{tabular}

\section{SCHOLARONE" Manuscripts}


Assessment of the influence of biophysical properties related to fuel conditions on fire severity using remote sensing techniques: a case study on a large fire in NW Spain

P. García-Llamas*a, S. Suárez-Seoane, A. Taboada ${ }^{\text {a }}$ V. Fernández-García ${ }^{a}$, J.M.

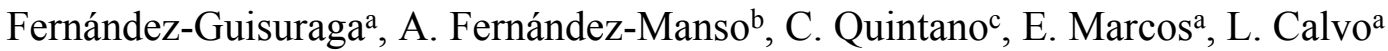

P. García-Llamas (corresponding author)

e-mail:pgarc1@unileon.es; phone: 0034987291567

a Area of Ecology, Faculty of Biological and Environmental Sciences, University of León, 24071 León, Spain. ${ }^{b}$ Agrarian Science and Engineering Department, University of León, Av. Astorga s/n, 24400 Ponferrada, Spain. ${ }^{c}$ Electronic Technology Department, Sustainable Forest Management Research Institute, University of Valladolid, Spanish National Institute for Agriculture and Food Research and Technology (INIA), C/ Paseo del Cauce, 59, 47011 Valladolid, Spain.

Date of the manuscript draft: September 2018

Manuscript word count: 3920 


\section{$1 \quad$ Abstract}

2 This study analyzes the suitability of remote sensing data from different sources

3 (Landsat 7 ETM+, MODIS and Meteosat) in evaluating the effect of fuel conditions on

4 fire severity, using a megafire (11891 ha) that occurred in a Mediterranean pine forest

5 ecosystem (NW Spain) between August $19^{\text {th }}$ and $22^{\text {nd }}, 2012$. Fire severity was measured

6 via the delta Normalized Burn Ratio index. Fuel conditions were evaluated through

7 biophysical variables including: (i) the Visible Atmospherically Resistant Index and

8 mean actual evapotranspiration, as proxies of potential live fuel amount; (ii) Land

9 Surface Temperature and water deficit, as proxies of fuel moisture content.

10 Relationships between fuel conditions and fire severity were evaluated using Random

11 Forest models. Biophysical variables explained $40 \%$ of the variance. The Visible

12 Atmospherically Resistant Index was the most important predictor, being positively associated with fire severity. Evapotranspiration also positively influenced severity, although its importance was conditioned by the data source. Live fuel amount, rather than fuel moisture content, primarily affected fire severity. Nevertheless, an increment in water deficit and land surface temperature was generally associated with greater fire severity. This study highlights that fuel conditions largely determine fire severity, providing useful information for defining pre-fire actions aimed at reducing fire effects.

Keywords: VARI index, evapotranspiration, Meteosat, MODIS, Landsat, fire effects 


\section{Introduction}

In the European Mediterranean region, fire is a major disturbance (Oliveira et al. 2012) with significant ecological and socio-economic impacts on forest ecosystems (Pausas et al. 2009). It is well established that a major determinant of the magnitude of the ecological impact and effects of wildfires is fire severity (Harris and Taylor 2017), as it can alter vegetation composition, structure and regeneration dynamics (Wang and Kemball 2003; González-De Vega et al. 2018), as well as contribute to increasing soil degradation (Heydari et al. 2017). Fire severity refers to the change between pre- and post-fire conditions (Key 2006; Meng et al. 2017; Fernández-García et al. 2018a), and is operationally represented as both aboveground and belowground consumption of organic matter (Keeley 2009). It has been commonly evaluated through field methods, (e.g., the Composite Burn Index - CBI - and the GeoCBI index); but also using remotely sensed spectral indices validated with field-measured metrics, as a timely and cost-effective alternative to field methods (Fang et al. 2018). Properties of fire regime, such as the severity and size of fires, are expected to increase in the future in the Mediterranean region, likely due to land use and climate change, and forest management policies (González-De Vega et al. 2016), which might lead to drastic shifts in fire activity and seasonality. Therefore, modelling potential fire severity and understanding its main drivers of control emerges as a priority for improving pre-fire forest management strategies (Estes et al. 2017; García-Llamas et al. 2019).

Among the environmental factors that influence fire severity, there is increasing evidence that fuel is a major controlling factor (Kraaij et al. 2018; García-Llamas et al. 2019). In forest ecosystems, fuel characteristics, such as fuel moisture and structure, may affect fire spread, progression and behaviour (Harris and Taylor 2017), which largely determines fire severity levels. Furthermore, fuel composition and loading influence heat flux during 
combustion, which ultimately may condition the spatial patterns of fire severity (Fang et al. 2018). Nevertheless, how fuel characteristics are specifically related to fire severity is still not fully understood. Whereas studies by Lentile et al. (2006) and Lydersen et al. (2017) have shown clear relationships between fuels and fire severity, others, such as Bessie and Johnson (1995) and Estes et al. (2017), suggested that fuels have a less important role on fire severity compared to other environmental factors (e.g., weather conditions and topography).

Fuel characteristics, such as fuel amount or spatial structure, can be modified through management treatments (Lee et al. 2018). As a consequence, knowledge of the role played by fuel in fire severity is critical for prioritizing effective pre- and post-fire management strategies. Fire management strategies require, however, the development of reliable and accurate information that helps and supports decision-making processes (Chuvieco and Kasischke 2007).

Recent advances in remote sensing techniques have provided major opportunities to obtain valuable information for scientists and decision-makers related to fuel characteristics for fire severity modelling in a cost-effective way. For example, satellite remote sensing offers great potential for (i) mapping fuel models (Riaño et al. 2002; van Wagtendonk and Root 2003); (ii) estimating live fuel moisture content from vegetation indices (Myoung et al. 2018); and (iii) measuring potential biomass production, the balance between moisture availability, fuel dryness and vegetation drought-stress from remotely sensed evapotranspiration products (Kane et al. 2015; Fang et al. 2018). Information from remote sensing systems offers several advantages as it is spatially comprehensive and can be periodically updated (Chuvieco and Kasischke 2007), thus enabling the assessment of spatial and temporal variation in fuel characteristics and their effect on fire severity. For example, Landsat satellite has been widely used for monitoring 
and modelling fuel characteristics, since it provides one of the longest moderate spatial resolution imagery collections (Banskota et al. 2014). Moderate Resolution Imaging Spectroradiometer (MODIS) vegetation products have also been commonly used in fire studies across the globe, due to their near-global spatial coverage and high temporal resolution (Uyeda et al. 2015; Fang et al. 2018). Additionally, characteristics of newer satellites, such as the high temporal resolution of Meteosat Second Generation (MSG; (Amraoui et al. 2013), are incurring interest in the fire research field. Nevertheless, despite its advantages, the operational use of remote sensing data in assessing the role of fuels in fire severity still presents some challenges associated with the current status of satellite sensor technology (Chuvieco and Kasischke 2007) and the availability of the spectral, spatial or temporal resolution required for operational performance (Meng and Zhao 2017).

In this study, we aim to examine the suitability of different remote sensing sources (Landsat 7 ETM+, MODIS and Meteosat) to evaluate how biophysical properties are related to fuel conditions and how they can predict fire severity. Further, we provide recommendations at management level for defining actions to reduce fire effects. As a case study, we used a megafire that occurred in 2012 in NW Spain, which affected 11891 ha of a Mediterranean ecosystem dominated by Pinus pinaster Aiton.

Methods

Study site

This study was conducted in the Sierra del Teleno mountain range (NW Spain; Fig. 1) where 11891 ha burned in August, 2012 (between $19^{\text {th }}$ and $22^{\text {nd }}$ ). The orography is 
101 heterogeneous with altitude ranging from 2188 to 840 m.a.s.l. and $10 \%$ average slope.

102 Soils are acidic originated over siliceous lithology (i.e., quartzite, conglomerate,

103 sandstone and slate) with low organic matter content (Fernández-García et al. 2018b).

104 The climate in this area is Mediterranean. Mean annual temperature is $10^{\circ} \mathrm{C}$, with $2-3$

105 months of drought in summer and a mean annual precipitation rate of 650 to $900 \mathrm{~mm}$

106 (20 years averaged values covering period 1950-1999; Ninyerola et al. 2005). During

107 the week preceding the fire and during the fire itself, there was a heatwave that

108 increased the fire risk (Quintano et al. 2015). The Sierra del Teleno mountain range has

109 frequently been affected by wildfires mainly associated to dry spring-summer lightning

110 storms and anthropic causes (Santamaría 2015). Small fires have commonly burned the

111 area during winter, spring and autumn, while large fires mainly occur during the

112 summer season (July-September; Santamaría 2015). The area affected by the fire was

113 dominated by a mature natural maritime pine (Pinus pinaster Ait.) forest, with a tree

114 density in mature stands of 765 plants ha $^{-1}$. The shrubby understory community is

115 mostly dominated by Erica australis L. and Pterospartum tridentatum (L.) Willk.

116 Maritime pine populations in this area are highly adapted to intense crown fires with

117 more than $95 \%$ of mature trees bearing serotinous cones (Tapias et al. 2004).

118 Nevertheless, short fire return intervals (the average fire free interval has been estimated

119 at 15 years) might prevent $P$. pinaster from reaching reproductive maturity, thus

120 undermining population resilience (Taboada et al. 2018). The fire under consideration

121 was an extreme convective-crown-fire that completely destroyed the understory and

122 consumed the majority of tree crowns $(40 \%$ of the surface burned at high severity

123 levels; Quintano et al. 2015). Such extreme fire severity characteristics justified the

124 selection of this fire event as a case study. 
127 Fire severity data were estimated from two Landsat 7 ETM+ images obtained on

128 September $20^{\text {th }}, 2011$ (pre-fire image) and September $20^{\text {th }}, 2012$ (post-fire image) from

129 the United States Geological Survey (USGS) Earth Explorer server

130 (http://earthexplorer.usgs.gov/). Image selection was conducted considering the

131 availability of cloud-free images closest to the date of the fire, aiming to avoid

132 phenological changes in the vegetation (Lecina-Díaz et al. 2014). We applied the

133 FLAASH algorithm (Berk et al. 1999; Matthew et al. 2003) to conduct atmospheric

134 correction of the images, which enabled us to obtain a Bottom of Atmosphere (BOA)

135 reflectance product.

136 Fire severity was calculated via the delta Normalized Burn Ratio (dNBR; Key and

137 Benson 2006; Eq. 1), an index widely used for estimating fire severity in forest systems

138 (Soverel et al. 2010; Whitman et al. 2018).

$140 \quad d N B R=\frac{N I R-S W I R}{N I R+S W I R}$

142 where the Near-Infrared (NIR) and the Short Wave Infrared (SWIR) bands used for

143 calculation were the NIR (B4) and the SWIR-2 (B7) bands of Landsat 7 ETM +. dNBR

144 values in unburned areas were normalized to zero by subtracting the average dNBR in

145 unburned areas outside the fire from those within the fire perimeter to account for inter-

146 annual phenological differences between pre- and post-fire images (Miller et al. 2009).

147 dNBR values were validated using the CBI index, which was estimated three months

148 after fire following the protocol described by Fernández-García et al. (2018a), which is

149 a modification of the CBI protocol developed by Key and Benson (2006). CBI values

150 ranged between 0 (unburned) and 3 (high severity) according to the burn severity scale 
by Key and Benson (2006). They were obtained averaging the scores assigned to several variables of five vertical strata, in 54 plots of $30 \mathrm{~m}$ x $30 \mathrm{~m}$ randomly distributed across the study area. The correlation value between the spectral index and CBI was 0.88 . See Fernández-García et al. (2018a) for further details on the dNBR validation.

In this study, we used continuous dNBR values as the response variable in further analysis. Nevertheless, for easier interpretation, we also show dNBR as classified fire severity using breakpoints defined based on the CBI values: low severity, $45.898 \geq$ dNBR $<413.185$; moderate severity, $413.185 \geq$ dNBR $<732.565$; high severity, $\geq$ 732.565; by Fernández-García et al. (2018b) (Fig. 1).

\section{Biophysical properties related to fuel conditions}

The biophysical properties related to fuel conditions were characterized by including metrics related to fuel loads and moisture content. We estimated the potential live fuel amount on the basis of two variables: (i) the Visible Atmospherically Resistant Index (VARI), and (ii) the mean actual evapotranspiration (AET). The VARI is an index based on the red, green and blue visible bands (Eq. 2; Gitelson et al. 2002), which is related to the live vegetation fraction and net primary production (Gitelson et al. 2002; Maguigan et al. 2016). It was derived from a Landsat 7 ETM+ image (30 m spatial resolution) obtained on September 20 $0^{\text {th }}, 2011$ (the pre-fire image applied for calculating fire severity; see section 2.2 for further details on image pre-processing).

$$
V A R I=\frac{R_{\text {green }}-R_{\text {red }}}{R_{\text {green }}+R_{\text {red }}-R_{\text {blue }}}
$$

where $\mathrm{R}_{\mathrm{band}}$ band=green, red and blue is the BOA reflectance for each band, respectively.

AET is related to potential biomass production and thus, to fuel amount (Kane et al. 2015). It was calculated by averaging information acquired between June and August, 2012 from two different remote sensing data sources: (i) a MSG (Schmetz et al. 2002; 
176 Romaguera et al. 2012) evapotranspiration product at 10-day intervals and $3 \mathrm{Km}$ spatial

177 resolution, provided by the EARS enterprise; (ii) the MOD16A2 global

178 evapotranspiration product at 8-day intervals and $500 \mathrm{~m}$ spatial resolution from MODIS

179 (https://modis.gsfc.nasa.gov/data/dataprod/mod16.php; Hantson et al. 2015). We

180 selected summer months because it is the season when large fires mainly occurred in the

181 area (Santamaría 2015), and it is well established that a main factor of fire ignition and

182 propagation is the presence of fuel ready for burning (Gouveia et al. 2012; Russo et al.

183 2017), especially in crown convective fires.

184 Variables accounting for fuel moisture content included the Land Surface Temperature

185 (LST) and water deficit, which were derived from the MODIS satellite. We estimated

186 these variables for the week prior to the fire because both the high temperatures and the

187 low relative humidity of the heatwave episode during the week preceding the fire likely

188 exacerbated the effects of summer drought and, thus, fuel desiccation and flammability

189 (van Mantgem et al. 2013). The LST, which is expected to increase in drier vegetation

190 (Dasgupta et al. 2005), was computed by averaging daily information from the MODIS

$1911 \mathrm{Km}$ LST product. Water deficit, at $500 \mathrm{~m}$ spatial resolution, was estimated as the

192 difference between PET and the AET (Kane et al. 2015). PET and AET were obtained

193 from the MOD16A2 global evapotranspiration product at 8-day intervals.

\section{Statistical analysis}

196 In order to explore the relationship between the response variable (fire severity) and the

197 predictors (biophysical variables related to fuel conditions), we applied the Random

198 Forest (RF) machine learning algorithm (Breiman 2001), using the 'randomForest'

199 package (Liaw and Wiener 2002) for R (R Core Team 2017) and a random sampling set

200 of 1000 pixels ( $1 \%$ of pixels from the image) to build the models. 
201 To avoid multicollinearity problems among the predictors, we previously checked

202 Pearson's bivariate correlations, the reached correlation values being lower than 0.60

203 (Supplementary material, Table 1).

204 The predictive power of RF was estimated through the internal out-of-bag error rates

205 (Kane et al. 2015). Furthermore, in order to obtain stable results, the parameter of $n$ tree

206 (i.e., the number of trees to run) was set to 500 and the mtry parameter (i.e., the number

207 of input predictors tested at each split) was established through initial tuning

208 experiments. The decrease in the accuracy (\% IncMSE) criterion was used to determine

209 the relative importance of predictors in the variance explained in models. RF models

210 were run 50 times and the average was provided as the final result, aiming to obtain

211 stable model outputs and to minimize stochastic errors. Additionally, we obtained

212 partial dependence plots for each predictor.

214 Results

215 Random Forest models accounted for approximately $40 \%$ of the fire severity variance.

216 Regarding the individual contribution of each predictor in explaining fire severity,

217 biophysical properties associated with the potential amount of live fuel were relatively

218 more important than those associated with fuel moisture content (Fig. 2). In detail, the

219 VARI index emerged as the most important predictor influencing fire severity (Fig. 2).

220 Overall, high values of the VARI index were related to an increment in fire severity levels,

221 thus indicating higher fire severity in areas of great availability of live fuel (Fig. 3 a).

222 Additionally, the importance of AET in Random Forest models changed between remote 223 sensing data sources of different spatial resolution (Fig. 2). Particularly, AET obtained

224 from MSG was the second most influential predictor explaining fire severity.

225 Nevertheless, AET derived from MODIS had less influence on fire severity, even less 
226 than biophysical properties related to fuel moisture content (i.e., water deficit) (Fig. 2).

227 Regardless of the remote sensing data source, higher AET values were correlated with 228 higher fire severity levels, but just towards a threshold (2.5 $\mathrm{mm}$ and $2.9 \mathrm{~mm}$ for AET from MSG and MODIS, respectively; Fig. 3 b, d). Increasing water deficit was generally associated with greater fire severity levels (Fig. 3 c). Furthermore, LST was weakly related to fire severity (Fig. 2) and exhibited a negative influence on fire severity (Fig. 3 e).

\section{Discussion}

\section{Influence of fuel on fire severity}

237 The results of this study confirm previous findings demonstrating the role of fuel

238 conditions, obtained from different remote sensing data sources, as major

239 controlling factors of fire severity patterns (Lentile et al. 2006; Gouveia et al.

240 2012; Kraaij et al. 2018). Nevertheless, in Mediterranean pine forest dominated by $P$. pinaster, results showed that fuel characteristics were not equally related to

242 fire severity. The amount of live fuel, measured through the VARI index,

243 appeared to be the most important factor, positively affecting fire severity.

244 Positive correlations between higher levels of fire severity and the presence of 245 dense live vegetation loads has also been reported in other areas dominated by

246 pine forests (Schoennagel et al. 2004; Arkle et al. 2012). In this context,

247 chemical properties of $P$. pinaster, such as high resin content, together with the

248 structural characteristics of needles, tend to increase live biomass flammability

249 and the energy released during combustion (Calvo et al. 2003), therefore contributing to higher fire severity levels. Additionally, recurrent fires in some 
zones of the study site have contributed to high post-fire regeneration stand densities (Calvo et al. 2013; Taboada et al. 2017), and resprouter shrub species [i.e., Erica australis L. and Pterospartum tridentatum (L.) Willk.] of high pyrogenicity (Calvo et al. 2008), which have been found to trigger high fire severity levels (García-Llamas et al. 2019).

The importance of live fuel on fire severity was also evinced by the overall positive effect of AET on fire severity, likely due to the association of this parameter with vegetation productivity and, thus, with mounts of live fuel (Kane et al. 2015). Nevertheless, the impact of AET on fire severity changed

260 substantially depending on the remote sensing data source used for analyses.

261 AET obtained from MSG was the second most important predictor of fire

262 severity, but the AET product from MODIS showed less importance than fuel moisture predictors (i.e., water deficit). The difference in spatial resolution between remote sensing derived AET products might justify this inconsistency in AET importance, thus indicating that the resolution might affect the

266 predictability of fire severity models (Harris and Taylor 2017; Fang et al. 2018).

267 In this context, it is well known that different spatial processes could operate at different scales and, hence, conclusions at one scale might not be enforceable at another (Suárez-Seoane and Baudry 2002; Wu and Li 2009). Consequently, spatial resolution discrepancies between data sources may constrain the accuracy

271 of models and lead to conflicting conclusions, thus limiting the development of 272 remote sensing applications (Wu and Li 2009; García-Llamas et al. 2016). As a result, although the capacity of remote sensing techniques to provide information

274 at multiple resolutions might be advantageous (Lentile et al. 2006), their utility 275 for assessing the role of fuel on fire severity might be hampered by mismatches 
276 between the resolution of the data source and the scale at which fuel

277 characteristics and fire severity correlate.

278 High fire severity levels have proven to be largely determined by fuel moisture content (Ferguson et al. 2002). Our results indicated that high-severity fires were

280 more likely under greater hydric stress conditions (i.e., higher water deficit and

281 LST values). This result might be explained by the fact that dry conditions tend

282 to favour the consumption of greater amounts of fuel, as well as higher levels of energy released during combustion (Dillon et al. 2011). Nevertheless, although summers in the Mediterranean Iberian Peninsula are typically dry enough to promote fuel desiccation that permits ignition, the abundance of live biomass loads for combustion, rather than fuel moisture, has been noted as the primary

287 limiting factor of fire severity (Pausas and Paula 2009; Lecina-Diaz et al. 2014), as also observed in our study. One reason could be that dry conditions limit vegetation growth and, thus, fuel accumulation and continuity, leading to a decrease in the risk of crown fire spread (Alvarez et al. 2012) and fire severity. Additionally, these results could also be related to scale issues, in a way that the spatial resolution of moisture predictors may not properly match the scale at which fire severity patterns and fuel moisture content characteristics correlate.

\section{Management recommendations}

296 Our findings evinced how high live fuel accumulations may increase

297 susceptibility to high-severity fire events in Mediterranean P. pinaster forest

298 ecosystems. Under this assumption, pre-fire management strategies aiming at

299 reducing high live fuel loads would be essential to reduce the likelihood of

300 severe fires. Effective pre-fire fuel treatments should prioritize the reduction of 
canopy bulk density through silvicultural treatments, aiming at hampering crown

302 fire spread, and dismissing fire intensity, as well as convective heat transfer into

303 the canopy, thus reducing fire severity (Lininger 2006). Additionally, creating

304 open and sparse stands and retaining large trees, which reduce fuel continuity,

305 would also be recommended, aiming to increase the resilience of the system

306 (Agee and Skinner 2005). In this way, studies by Gallegos et al. (2003) and Kim

307 et al. (2016) showed how a relatively open forest structure was correlated with a

308 decrease in fire severity. Nevertheless, it is necessary to consider that fuel

309 reduction treatments need to be balanced against the development of fire-prone

310 understory vegetation. In this context, stand opening might enhance the

311 development of fire-prone shrubby understory (Fernandes and Rigolot 2007) and

312 the desiccation of live and dead fuels (Peterson et al. 2003), which would make

313 periodic surface fuel treatments necessary.

\section{Conclusions}

316 The results of this study highlight that, in severe crown-convective fires in P. pinaster

317 Mediterranean forest, the accumulation of live vegetation available to be burned plays a

318 relatively more important role in determining high levels of fire severity than fuel

319 moisture conditions. In addressing the role of fuel characteristics in fire severity, the

320 VARI index from Landsat 7 ETM+ and the AET product from MSG might be valuable

321 tools for determining the amount of live fuel susceptible to influencing fire severity.

322 However, we further highlight the importance of a proper selection of the remote data

323 sources at the operational spatial resolution which might affect the predictability of fire

324 severity models. Our analysis provides information that can be helpful for

325 environmental managers when defining strategies aimed at reducing severity and its 
326 ecological effects during the pre- and post-fire decision-making process. These

327 strategies should prioritize the reduction of live fuel accumulations and the

328 enhancement of a more open canopy through the modification of forest stands and

329 structure.

330

331 Conflicts of interest

332 The authors declare no conflicts of interest.

333

334 Acknowledgements

335 Financing for this study was provided by the Spanish Ministry of Economy and

336 Competitiveness (GESFIRE project, AGL2013-48189-C2-1-R; FIRESEVES project,

337 AGL2017-86075-C2-1-R), the Regional Government of Castile and León (FIRECYL

338 project, LE033U14; SEFIRECYL project, LE001P17), and the European Regional

339 Development Fund. Further, V. Fernández-García and J.M. Fernández-Guisuraga were

340 supported by a predoctoral fellowship from the Ministry of Education, Culture and

341 Sport of Spain (FPU14/00636 and FPU16/03070). 


\section{References}

344 Alvarez A, Gracia M, Vayreda J, Retana J (2012) Patterns of fuel types and Crown fire 345 potential in Pinus halepensis forests in the Western Mediterranean Basin. Forest 346 Ecology and Management 270, 282-290.

347 Agee JK, Skinner CN (2005) Basic principles of forest fuel reduction treatments. Forest $348 \quad$ Ecology and Management 211, 83-96.

349 Amraoui M, Liberato MLR, Calado TJ, DaCamara CC, Pinto-Coelho L, Trigo RM, 350 Gouveia CM (2013) Fire activity over Mediterranean Europe based on information 351 from Meteosat-8. Forest Ecology and Management 294, 62-75.

352 Arkle RS, Pilliod DS, Welty JL (2012) Pattern and process of prescribed fires influence 353 effectiveness at reducing wildfire severity in dry coniferous forests. Forest Ecology and Management 276, 174-184.

Banskota A, Kayastha N, Falkowski MJ, Wulder MA, Froese RE, White JC (2014) Forest monitoring using Landsat time series data: a review. Canadian Journal of Remote Sensing 40, 362-384.

Berk A, Anderson GP, Bernstein LS, Archarya PK, Dothe H, Matthew MW, Michael W, Adler-Golden SM, Chetwynd JH, Richtsmeier SC, Pukall B, Allred CL, Jeong LS, Hoke ML (1999) MODTRAN4 radiative transfer modelling for atmospheric correction. Proceedings of SPIE 3756, 348-353.

362 Bessie WC, Johnson EA (1995) The relative importance of fuels and weather on fire

363 behavior in subalpine forests. Ecology 76(3), 747-762.

364 Breiman L (2001) Random forests. Machine learning 45(1), 5-32.

365 Calvo L, Santalla S, Marcos E, Valbuena L, Tárrega R, Luis E (2003) Regeneration after wildfire in communities dominated by Pinus pinaster, an obligate seeder, and in others 
dominated by Quercus pyrenaica, a typical resprouter. Forest Ecology and Management 184, 209-223.

Calvo L, Santalla S, Valbuena L, Marcos E, Tárrega R, Luis-Calabuig E (2008) Postfire natural regeneration of a Pinus pinaster forest in NW Spain. Plant Ecology 197, $81-90$

Calvo L, Santalla S, Valbuena L, Marcos E, Tárrega R, Luis-Calabuig E (2008) Postfire natural regeneration of a Pinus pinaster forest in NW Spain. Plant Ecology 197, 81-90.

Chuvieco E, Kasischke ES (2007) Remote sensing information for fire management and fire effects assessment. Journal of Geophysical Research 112, G01S90.

Dasgupta S, Qu JJ, Hao X (2005) Evaluating remotely sensed live fuel moisture estimations for fire behavior predictions. EastFIRE Conference. (Fairfax, VA).

Dillon GK, Holden ZA, Morgan P, Crimmins MA, Heyerdahl EK, Luce CH (2011) Both topography and climate affected forest and woodland burn severity in two regions of the western US, 1984 to 2006. Ecosphere 2(12), 1-33.

Estes BL, Knapp EE, Skinner CN, Miller JD, Preisler HK (2017) Factors influencing fire severity under moderate burning conditions in the Klamath Mountains, northern California, USA. Ecosphere 8(5), e01794.

Fang L, Yang J, White M, Liu Z (2018) Predicting potential fire severity using vegetation, topography and surface moisture availability in a Eurasian boreal forest landscape. Forests 9(3), 130.

Ferguson SA, Ruthford JE, McKay SJ, Wright D, Wright C, Ottmar R (2002) Measuring moisture dynamics to predict fire severity in longleaf pine forests. International Journal of Wildland Fire 11(4), 267-279. 
391

Fernandes PM, Rigolot E (2007) The fire ecology and management of maritime pine (Pinus pinaster Ait.). Forest Ecology and Management 241, 1-13.

Fernández-García V, Santamarta M, Fernández-Manso A, Quintano C, Marcos E, Calvo E (2018a) Burn severity metrics in fire-prone pine ecosystems along a climatic gradient using Landsat imagery. Remote Sensing of Environment 206, 205-217.

Fernández-García V., Quintano C, Taboada A, Marcos E, Calvo L, Fernández-Manso A (2018b) Remote sensing applied to the study of fire regime attributes and their influence on post-fire greenness recovery in pine ecosystems. Remote Sensing 10(5), 733.

Gallegos V, Navarro RM, Fernández P, Valle G (2003) Postfire regeneration in Pinus pinea L. and Pinus pinaster Aiton in Andalucia (Spain). Environmental Management 31(1), 86-99.

García-Llamas P, Calvo L, Álvarez-Martínez JM, Suárez-Seoane S (2016) Using remote sensing products to classify landscape. A multi-spatial resolution approach. International Journal of Applied Earth Observation and Geoinformation 50, 95-105.

García-Llamas P, Suárez-Seoane S, Taboada A, Fernández-Manso A, Quintano C, Fernández-García V, Fernández-Guisuraga JM, Marcos E, Calvo L (2019)

Environmental drivers of fire severity in extreme fire events that affect Mediterranean pine forest ecosystems. Forest Ecology and Management 433, 24-32.

Gitelson AA, Stark R, Grits U, Rundquist D, Kaufman Y, Derry D (2002) Vegetation and soil lines in visible spectral space: a concept and technique for remote estimation of vegetation fraction. International Journal of Remote Sensing 23(13), 2537-2562.

González-De Vega S, De las Heras J, Moya D (2016) Resilience of Mediterranean terrestrial ecosystems and fire severity in semiarid areas: responses of Aleppo pine 

1177.

417 González-De Vega S, De las Heras J, Moya D (2018) Post-fire regeneration and diversity response to burn severity in Pinus halepensis Mill. Forest. Forest 9(6), 299.

Gouveia CM, Bastos A, Trigo RM, DaCamara CC (2012) Drought impacts on vegetation in the pre- and post-fire events over Iberian Peninsula. Natural Hazards and Earth System Sciences 12, 3123-3137.

Harris L, Taylor AH (2017) Previous burns and topography limit and reinforce fire severity in a large wildfire. Ecosphere 8(11), e02019.

Heydari M, Rostamy A, Najafi F, Dey DC (2017) Effect of fire severity on physical and biochemical soil properties in Zagros oak (Quercus brantii Lindl.) forests in Iran. Journal of Forestry Research 28(1), 95-104. PM (2015) Water balance and topography predict fire and forest structure patterns. Forest Ecology and Management 338, 1-13.

Keeley JE (2009) Fire intensity, fire severity and burn severity: a brief review and suggested usage. International Journal of Wildland Fire 18(1), 116-126.

Key CH (2006) Ecological and sampling constraints on defining landscape fire severity.

Key CH, Benson NC (2006) Landscape Assessment (LA) sampling and analysis methods. USDA Forest Service General Technical Reports RMRS-GTR-164-CD.

Kim DW, Chung W, Lee B (2016) Exploring tree crown spacing and slope interaction Technology 12(4), 167-175. 
439 Kraaij T, Baard JA, Arndt J, Vhengani L, van Wilgen BW (2018) An assessment of

440 climate, weather, and fuel factors influencing a large, destructive wildfire in the

$441 \quad$ Knysna region, South Africa. Fire Ecology 14(4), 1-12.

442 Lecina-Diaz J, Alvarez A, Retana J (2014) Extreme fire severity patterns in

443 topographic, convective and wind-driven historical wildfires of Mediterranean pine

$444 \quad$ forests. Plos ONE 9(1), e85127.

445 Lee HJ, Choi YE, Lee SW (2018) Complex relationships of the effects of topographic

446 characteristics and susceptible tree cover on burn severity. Sustainability 10(2), 295.

447 Lentile LB, Holden ZA, Smith AMS, Falkowski MJ, Hudak AT, Morgan P, Lewis SA,

448 Gessler PE, Benson NC (2006) Remote sensing techniques to assess active fire

449 characteristics and post-fire effects. International Journal of Wildland Fire 15(3),

$450 \quad 319-345$.

451 Liaw A, Wiener M (2002) Classification and regression by randomForest. $R$ News 2, 18-

452 22. http://CRAN.R-project.org/doc/Rnews/

453 Lininger JC (2006) Effectiveness of stand-scale forest restoration, Siskiyou Mountains,

454 Oregon. Thesis dissertation. (University of Montana: Montana).

455 Lydersen JM, Collins BM, Brooks ML, Matchett JR, Shive KL, Povak NA, Kane VR, 456 Smith DF (2017) Evidence of fuels management and fire weather influencing fire

457 severity in an extreme fire event. Ecological Applications 27(7), 2013-2030.

458 Maguigan M, Rodgers J, Dash P, Meng Q (2016) Assessing net primary production in

459 montane wetlands from proximal, airbone and satellite remote sensing. Advances in

$460 \quad$ Remote Sensing 5(2), 118-130.

461 Matthew MW, Alder-Golden SM, Berk A, Felde G, Anderson GP, Gorodetzky D,

462 Paswaters S, Shippert M (2003). Atmospheric correction of spectral imagery: 
evaluation of the FLAASH algorithm with AVIRIS data. Proceedings of SPIE 5093, 474- 482.

Meng R, Zhao F (2017) Remote sensing of fire effects. A review for recent advances in burned area and burn severity mapping. In 'Remote Sensing of Hydrometeorological Hazards'. (Eds GP Petropoulos, T Islam) 525 pp. (CRC Press: Boca Ratón).

Meng R, Wu J, Schwager KL, Zhao F, Dennison PE, Cook BD, Brewster K, Green TM, Serbin SP (2017) Using high spatial resolution satellite imagery to map forest burn severity across spatial scales in a Pine Barrens ecosystem. Remote Sensing of Environment 191, 95-109.

Miller JD, Safford HD, Crimmins M, Thode AE (2009) Quantitative evidence for increasing forest fire severity in the Sierra Nevada and southern Cascade Mountains, California and Nevada, USA. Ecosystems 12(1), 16-32.

Myoung B, Kim SH, Nghiem SV, Jia S, Whitney K, Kafatos MC (2018) Estimating live fuel moisture from MODIS satellite data for wildfire danger assessment in Southern California USA. Remote Sensing 10(1), 87.

Ninyerola M, Pons X, Roure JM (2005) Atlas Climático Digital de la Península Ibérica. Metodología y Aplicaciones en Bioclimatología y Geobotánica. (Universidad Autónoma de Barcelona, Bellaterra: Barcelona).

Oliveira S, Oehler F, San-Miguel-Ayanz J, Camia A, Pereira JMC (2012) Modelling spatial patterns of fire occurrence in Mediterranean Europe using Multiple Regression and Random Forest. Forest Ecology and Management 275, 117-129.

Pausas JG., Llovet, J., Rodrigo, A., Vallejo, R. (2008) Are wildfires a disaster in the Mediterranean basin? - A review. International Journal of Wildfire 17, 713-723. 
Peterson DL, Johnson MC, Agee JK, Jain TB, McKenzie D, Reinhardt ED (2003) Fuels planning: managing forest structure to reduce fire hazard. Proceedings of the Second International Wildland Fire Ecology and Fire Management Congress. (Orlando: Florida).

Quintano C, Fernández-Manso A, Calvo L, Marcos E, Valbuena L (2015) Land surface temperature as potential indicator of burn severity in forest Mediterranean ecosystems. International Journal of Applied Earth Observation and Geoinformation 36, 1-12.

R Core Team (2017) R: a language and environment for statistical computing. Available from: https://www.R-project.org/

Riaño D, Chuvieco E, Salas J, Palacios-Orueta A, Bastarrika A (2002) Generation of fuel type maps from Landsat-TM images and auxiliary data in Mediterranean ecosystem. Canadian Journal of Forest Research 32(8), 1301-1315.

Romaguera M, Krol MS, Salama MS, Hoekstra AY, Su Z (2012) Determining irrigated areas and quantifying blue water use in Europe using remote sensing Meteosat Second Generation (MSG) products and Global Land Data Assimilation System (GLDAS) data. Photogrammetric Engineering \& Remote Sensing 78(8), 861-873. Assessing the role of drought events on wildfires in the Iberian Peninsula. Agricultural and Forest Meteorology 237, 50-59.

Santamaría JE (2015) El pino pinaster ne la Sierra del Teleno historia, ordenación,

510 Schmetz J, Pili P, Tjemkes S, Just D, Kerkmann J, Rota S, Ratier A (2002) An

511 introduction to Meteosat Second Generation (MSG). American Meteorological 
513 Schoennagel T, Veblen TT, Romme WH (2004) The interaction of fire, fuels and

$514 \quad$ climate across Rocky Mountain Forests. BioScience 54(7), 661-676.

Soverel NO, Perrakis DDB, Coops NC (2010) Estimating burn severity from Landsat dNBR and RdNBR indices across western Canada. Remote Sensing of Environment 114(9), 1896-1909.

Suárez-Seoane S, Baudry J (2002) Scale dependence of spatial patterns and cartography on the detection of landscape change: relationships with species' perception. Ecography 25(4), 499-511.

Taboada A, Tarrega R, Marcos E, Valbuena L, Suárez-Seoane S, Calvo L (2017) Fire recurrence and emergency post-fire management influence seedling recruitment and growth by altering plant interactions in fire-prone ecosystems. Forest Ecology and Management 402, 63-75.

Taboada A, Fernández-García V, Marcos E, Calvo L (2018) Interactions between large high-severity fires and salvage logging on a short return interval reduce the regrowth of fire-prone serotinous forests. Forest Ecology and Management 414, 54-63

Tapias R, Climent J, Pardos JA, Gil L (2004) Life histories of Mediterranean pines Plant Ecology 171, 53-68.

Uyeda KA, Stow DA, Riggan PJ (2015) Tracking MODIS NDVI time series to estimate fuel accumulation. Remote Sensing Letters 6(8), 587-596. stress increases forest fire severity across the western United States. Ecology Letters 16(9), 1151-1156.

van Wagtendonk JW, Root RR (2003) The use of multitemporal Landsat Normalized 
538 Wang GG, Kemball KJ (2003) The effect of fire severity on early development of

539 understory vegetation following a stand replacing wildfire. 5th Symposium on Fire

540 and Forest Meteorology jointly with 2nd International Wildland Fire Ecology and

541 Fire Management Congress. (Orlando, FL).

542 Whitman E, Parisien MA, Thompson DK, Hall RJ, Skakun RS, Flannigan MD (2018)

543 Variability and drivers of burn severity in the northwestern Canadian boreal forest.

$544 \quad$ Ecosphere 9(2), e02128.

545 Wu H, Li ZL (2009) Scale issues in remote sensing: a review on analysis, processing $546 \quad$ and modeling. Sensors 9, 1768-1793.

547 


\section{$548 \quad$ Figures}

550 Fig. 1 Location map of the study area (Sierra del Teleno, NW Spain) including a

551 pre-fire vegetation map of the burned area produced using: a) an

552 orthophotograph (year 2011) from the Spanish National Plan for Aerial

553 Orthophotography

554 (http://centrodedescargas.cnig.es/CentroDescargas/index.jsp\#); b) the CORINE

555 Land Cover data base available for 2012; and c) a fire severity map obtained

556 using classified dNBR values derived from Landsat 7 ETM+ post-burned

557 imagery $\left(20^{\text {th }}\right.$ September 2012) with breakpoints defined based on the CBI

558 values: low severity, $45.898 \geq \mathrm{dNBR}<413.185$; moderate severity, $413.185 \geq$

559 dNBR $<732.565$; high severity, $\geq 732.565$ from Fernández-García et al.

560 (2018b); b)

561 Fig. 2 Relative importance, measured as \% IncMSE, of variables from Random

562 Forest models explaining fire severity. Abbreviations are Actual

563 Evapotranspiration from Meteosat Second Generation satellite $\left(\mathrm{AET}_{\mathrm{MSG}}\right)$ and

564 from MODIS satellite (AET MODIS $_{\text {); }}$ and Land Surface Temperature (LST).

565 Fig. 3 Partial dependence plots showing the relationship between fire severity

566 and each of the predictors included in Random Forest models: a) VARI index; b)

567 Actual Evapotranspiration from Meteosat Second Generation satellite (AET $\mathrm{ASG}_{\mathrm{M}}$ );

568 c) Water deficit; d) Actual Evapotranspiration from the MODIS satellite

569 (AET MODIS $_{\text {) }}$ e) Land Surface Temperature (LST). 
$574 \quad$ Fig. 1

575

57
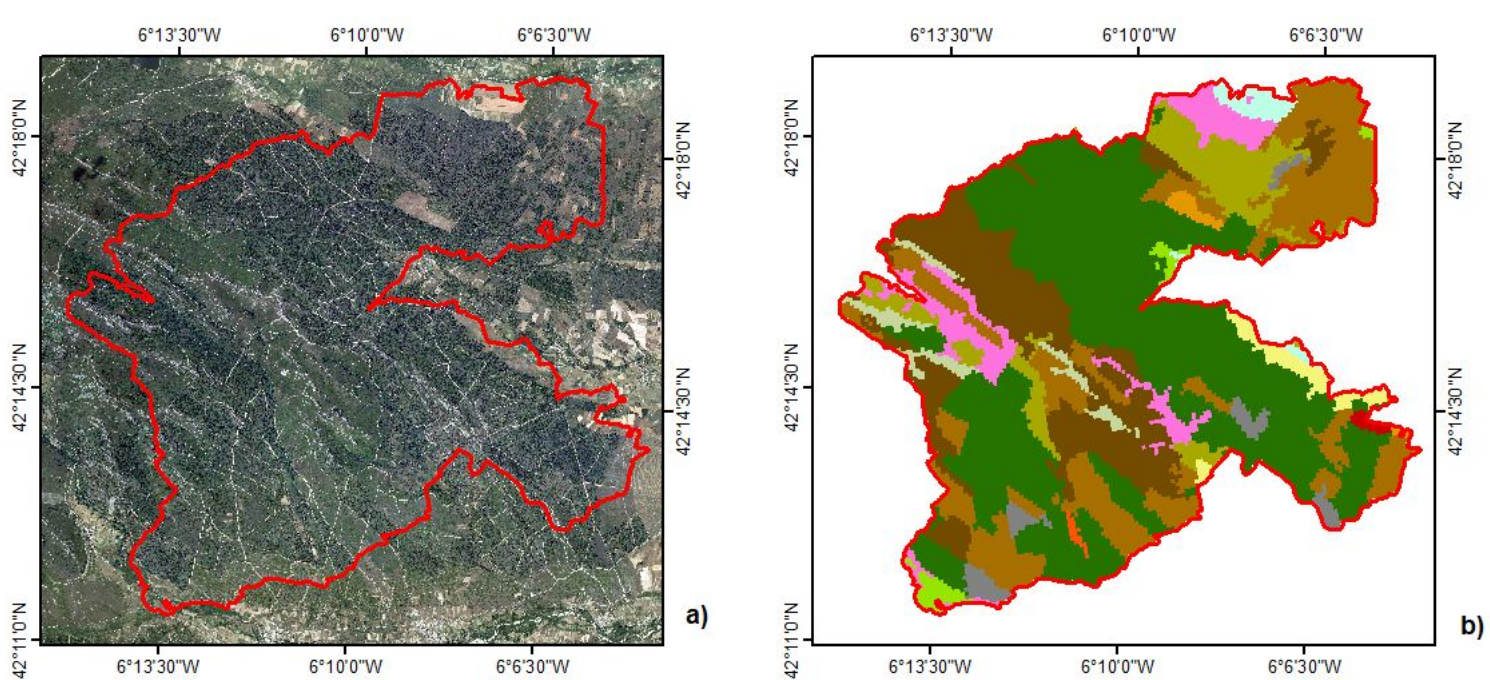

58

59

59

59

59

59

59

59

59

59

59

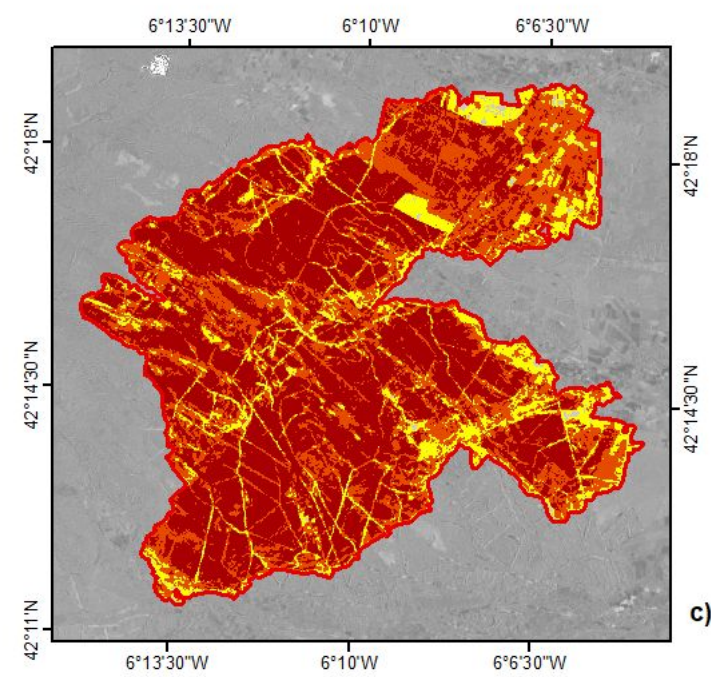

Vegetation map

$\square$ Non-irrigated arable land

$\square$ Permanently irrigated land

Mixed forest

$\square$ Pastures

$\square$ Natural grasslands

Complex cultivation patterns

Moors and heathland Sclerophyllous vegetation

Land principally occupied by agriculture Transitional woodland-shrub

$\square$ Broad-leaved forest $\square$ Sparsely vegetated areas

Coniferous forest

Severity levels

$\square$ No change

$\square$ Low

Moderate

High

$\square$ Fire perim eter
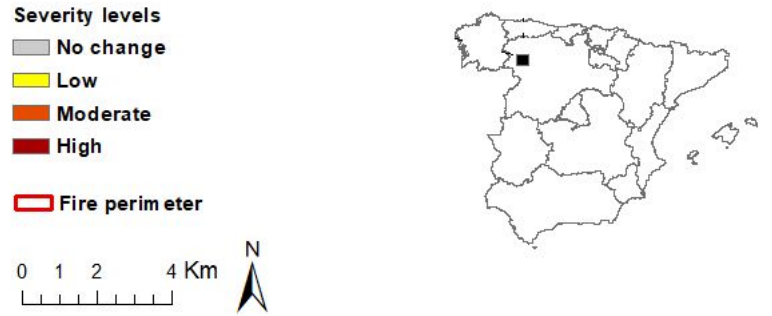

60

60

$6^{\circ} 13^{\prime} 30^{\prime \prime} \mathrm{W}$

$6^{\circ} 10^{\circ} \mathrm{W}$

c)

60

606

607

608

609

610

611

612

613

614

615

616

617

618

619

620 
$621 \quad$ Fig. 2

622

623

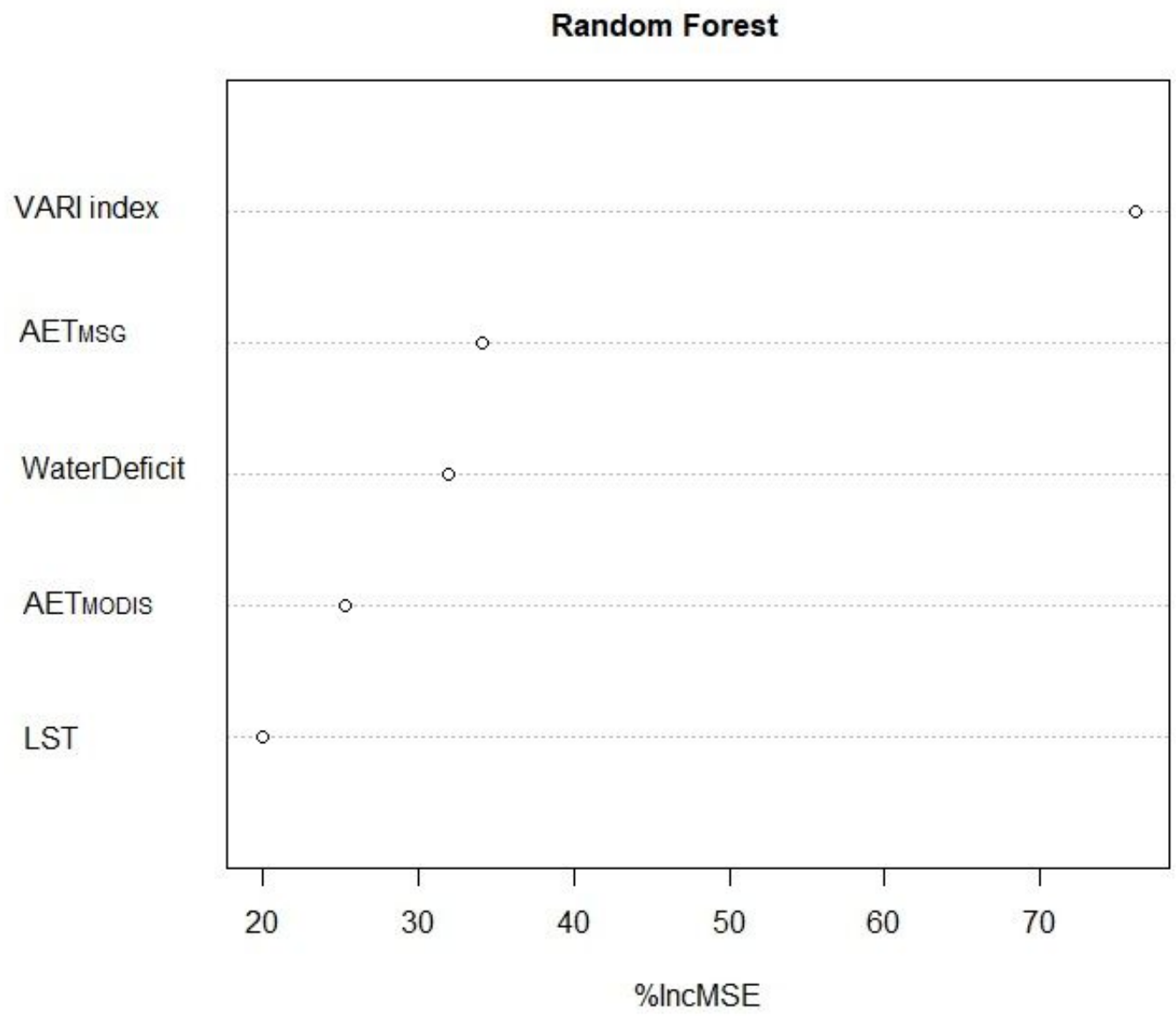

624

625

626

627

628

629

630

631

632

633

634

635

636

637

638

639

640

641

642

643

644

645 


\section{$646 \quad$ Fig. 3}

647
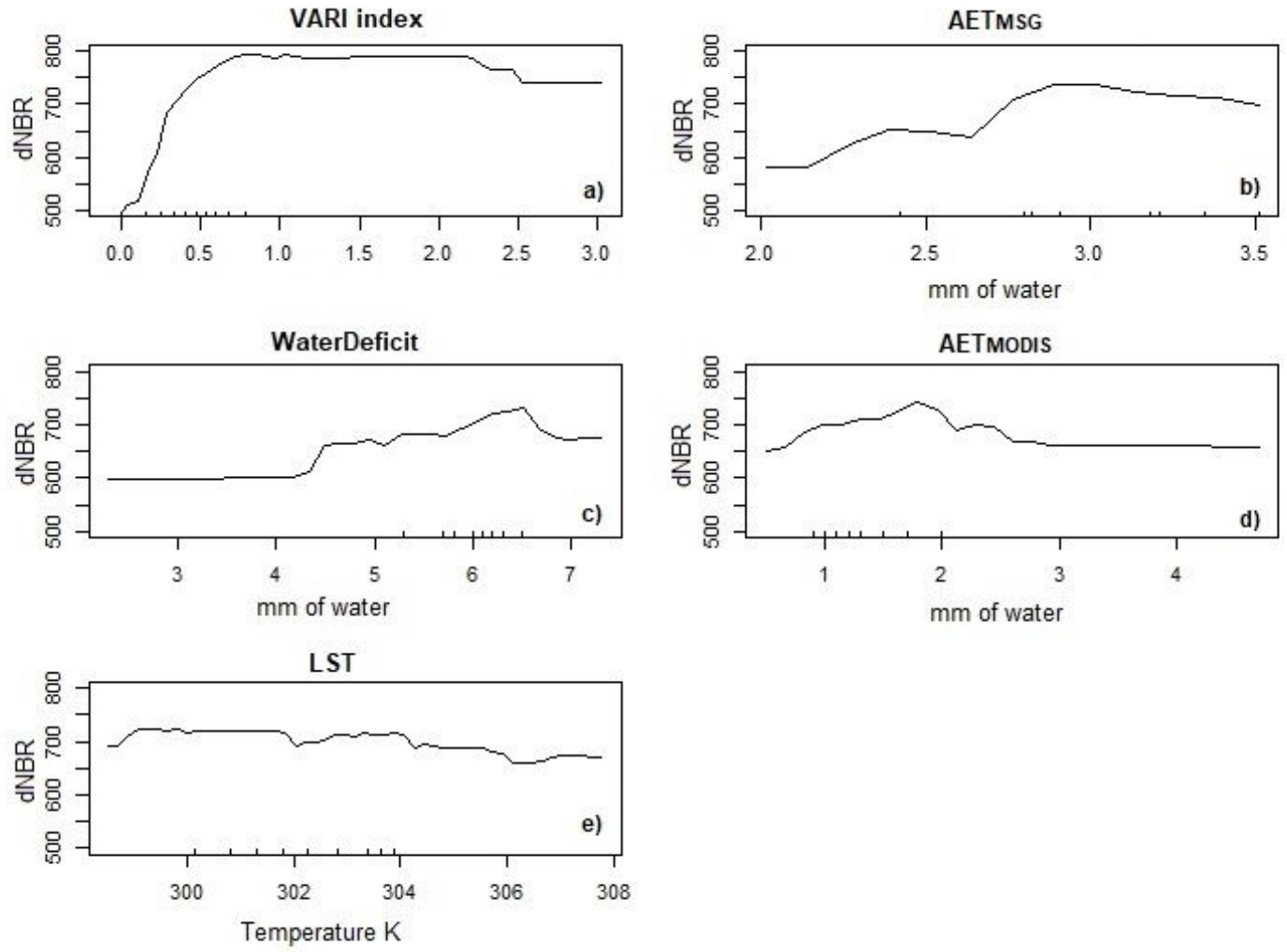
Potential live fuel amount had more influence on fire severity than fuel moisture content on pine forest ecosystems. The Visible Atmospherically Resistant Index, as a proxy of live fuel amount, showed the strongest association with fire severity. Remote sensing has high potential for determining fuel characteristics susceptible to influencing fire severity, although spatial resolution might constrain the utility of fire severity models. 

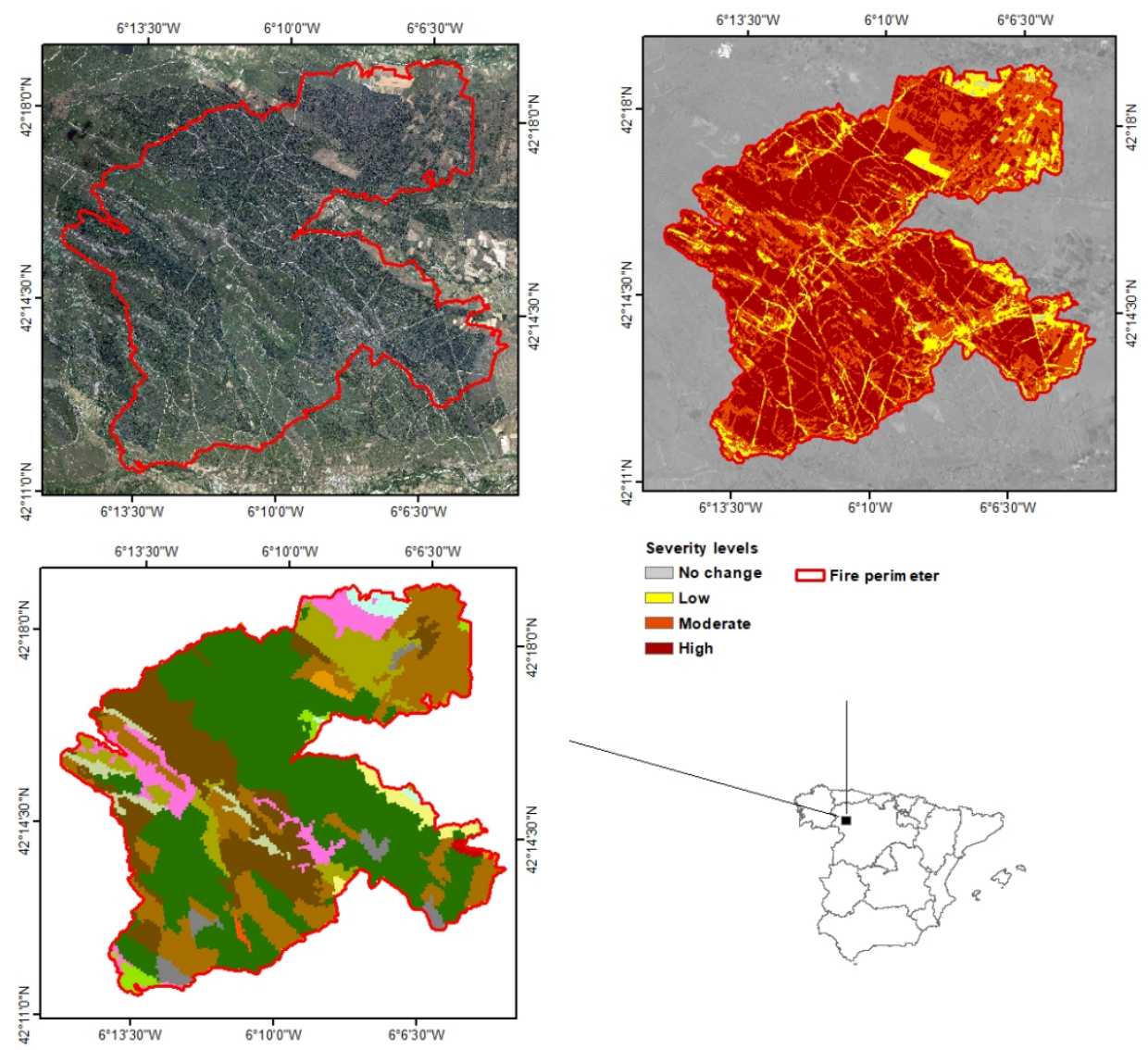

$$
\begin{aligned}
& \text { Severity levels } \\
& \square \text { No change } \square \text { Fire perim eter } \\
& \square \text { Low } \\
& \text { Moderate } \\
& \text { High }
\end{aligned}
$$

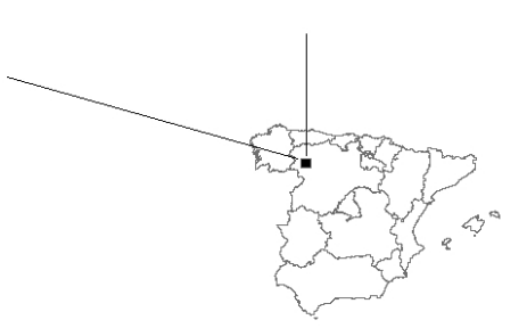

Vegetation map
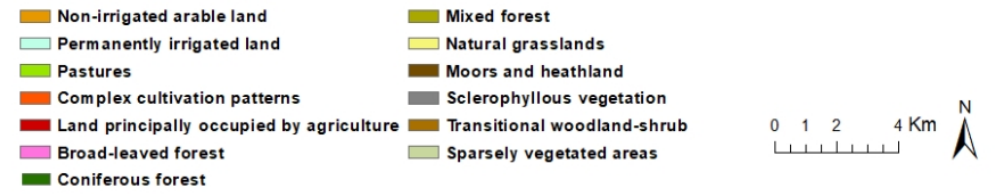

Fig. 1 Location map of the study area (Sierra del Teleno, NW Spain) including a pre-fire vegetation map of the burned area produced using: a) an orthophotograph (year 2011) from the Spanish National Plan for Aerial Orthophotography (http://centrodedescargas.cnig.es/CentroDescargas/index.jsp\#); b) the CORINE Land Cover data base available for 2012; and c) a fire severity map obtained using classified dNBR values derived from Landsat 7 ETM+ post-burned imagery (20th September 2012) with breakpoints defined based on the CBI values: low severity, $45.898 \geq \mathrm{dNBR}<413.185$; moderate severity, $413.185 \geq \mathrm{dNBR}<$ 732.565; high severity, $\geq 732.565$ from Fernández-García et al. (2018b); b) 


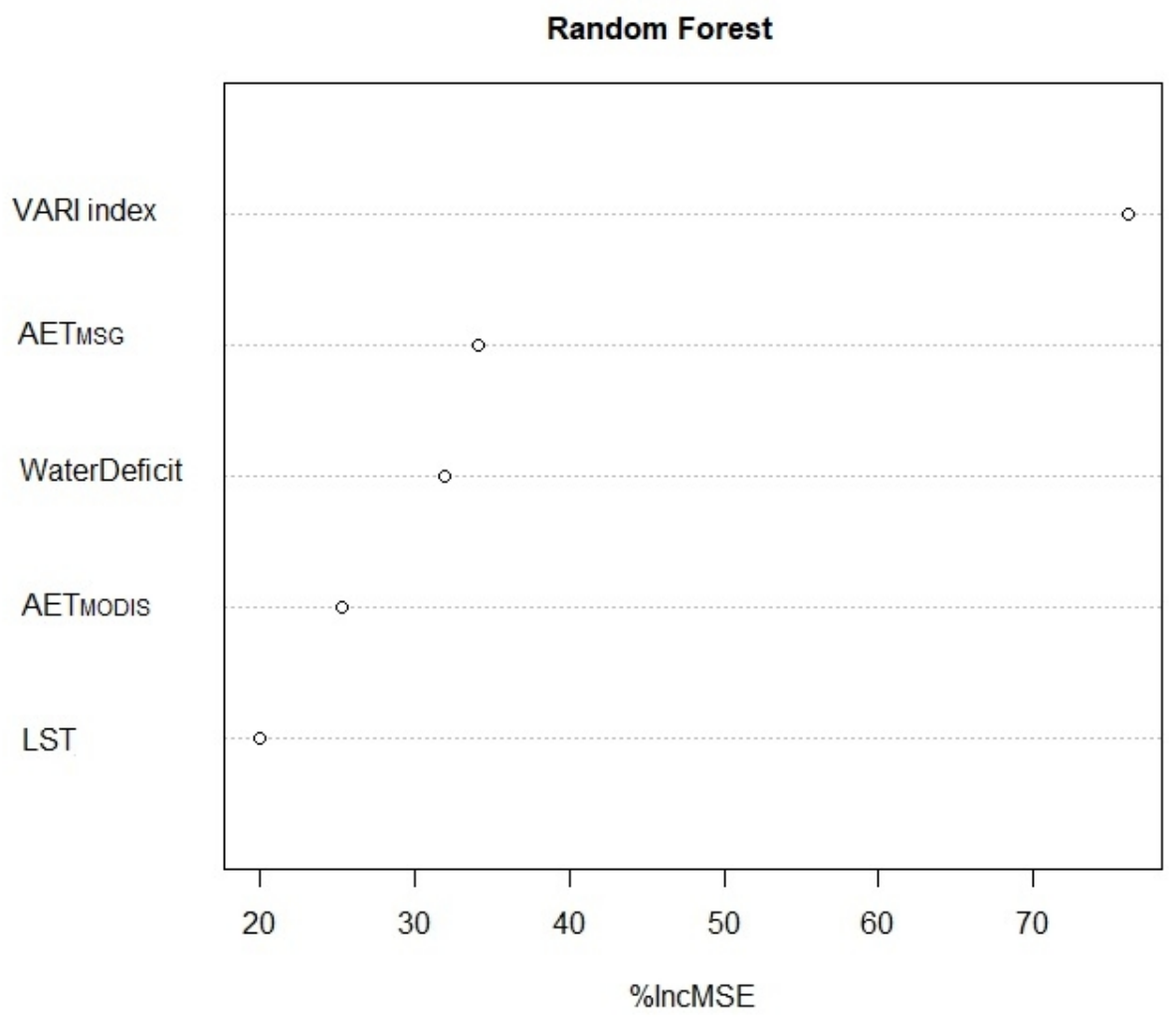

Fig. 2 Relative importance, measured as \% IncMSE, of variables from Random Forest models explaining fire severity. Abbreviations are Actual Evapotranspiration from Meteosat Second Generation satellite (AETMSG) and from MODIS satellite (AETMODIS); and Land Surface Temperature (LST).

$183 \times 157 \mathrm{~mm}(96 \times 96 \mathrm{DPI})$ 

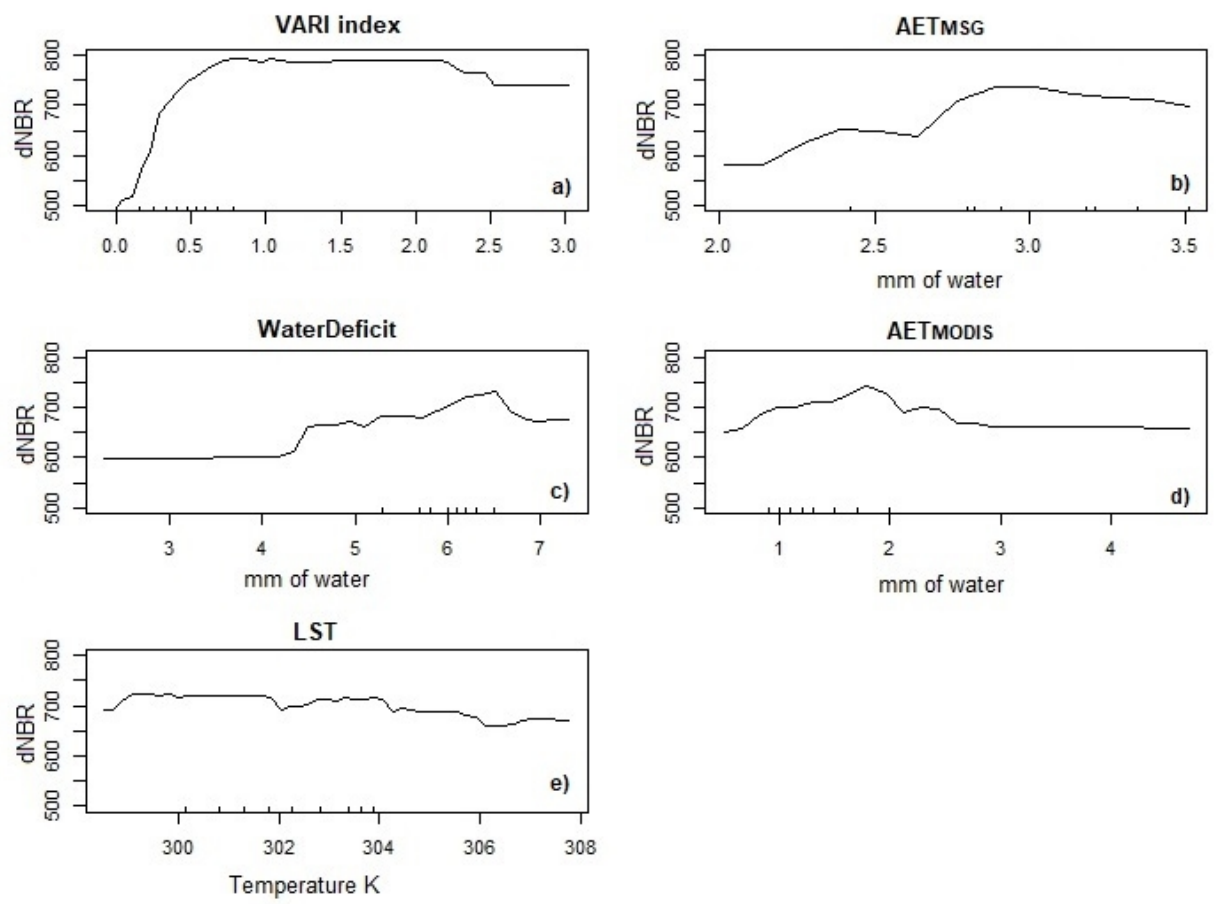

Fig. 3 Partial dependence plots showing the relationship between fire severity and each of the predictors included in Random Forest models: a) VARI index; b) Actual Evapotranspiration from Meteosat Second Generation satellite (AETMSG); c) Water deficit; d) Actual Evapotranspiration from from MODIS satellite (AETMODIS); e) Land Surface Temperature (LST).

$194 \times 139 \mathrm{~mm}(96 \times 96 \mathrm{DPI})$ 
Table 1. Pearson's correlation coefficients $(r)$ between pairs of predictors (biophysical variables related to fuel conditions)

\begin{tabular}{lccccc}
\hline & VARI index & AET $_{\text {MODIS }}$ & AET $_{\text {MSG }}$ & Water deficit & LST \\
\hline VARI index & 1.00 & 0.00 & -0.01 & 0.00 & -0.11 \\
AET $_{\text {MODIS }}$ & 0.00 & 1.00 & -0.60 & 0.53 & -0.21 \\
AET $_{\text {MSG }}$ & -0.01 & -0.60 & 1.00 & -0.61 & 0.35 \\
Water deficit & 0.00 & 0.53 & -0.61 & 1.00 & -0.43 \\
LST & -0.11 & -0.21 & 0.35 & -0.43 & 1.00 \\
\hline
\end{tabular}

$\mathrm{AET}_{\text {MODIS }}$ (Actual Evapotranspiration obtained from the MOD16A2 global evapotranspiration product); $\mathrm{AET}_{\mathrm{MSG}}$ (Actual Evapotranspiration obtained from the Meteosat Second Generation). 